\title{
Light microscopy studies on mice testis after the nutritional supplement chromium(III)-tris(picolinate)
}

\author{
M. Ferreira*, T.M. Santos** and M.L. Pereira* \\ *Departamento de Biologia e CICECO, Centro de Investigação em Materiais Cerâmicos e Compósitos, \\ Universidade de Aveiro, Campus de Santiago, 3810-193 Aveiro, Portugal \\ **Departamento de Química e CICECO, Centro de Investigação em Materiais Cerâmicos e Compósitos, \\ Universidade de Aveiro, Campus de Santiago, 3810-193 Aveiro, Portugal
}

$\mathrm{Cr}(\mathrm{III})$-tris(picolinate), $\left[\mathrm{Cr}(\text { pic })_{3}\right]$, is a very common dietary supplement, recommended for humans, cattle and swine. Chromium is considered an essential trace element, when in oxidation state +3 , with some of its compounds seeming to have a beneficial effect on blood sugar regulation mechanisms. However, the safety of the use of a particularly popular $\mathrm{Cr}(\mathrm{III})$ compound, ie $\left[\mathrm{Cr}(\mathrm{pic})_{3}\right]$, remains debatable. Clastogenic, and mutagenic features have been reported by Stearns and co-workers ${ }^{[1]}$, although surrounded by a controversial and contradictory multitude of publications on this subject ${ }^{[2,3]}$. The present work aims to study the effects of $\left[\mathrm{Cr}(\mathrm{pic})_{3}\right]$ on mice spermatogenesis.

Cr(III)-tris(picolinate) was synthesized and characterized according to the literature ${ }^{[1]}$. Its composition as a mononuclear complex was tested by ESI-MS and by X-ray powder diffraction followed by single-crystal simulation calculations.

Male adult CDI mice from Harlan (Spain) were divided in groups and orally given $25 \mathrm{mg} / \mathrm{kg}$ and $50 \mathrm{mg} / \mathrm{kg} / \mathrm{body}$ weigh/daily of $\left[\mathrm{Cr}(\mathrm{pic})_{3}\right]$ for two weeks. Controls were also done. Behaviour and body weight were monitored throughout the experiments. After sacrifice, testis were collected, weighed, and fixed in Bouin's solution. Organs were then prepared for histology using routine techniques. Animal experiments were conducted according to ethics procedures. Histological sections of control group evidenced normal regular features (Fig. 1a). However considerable damage was observed in both experimental groups in a dose dependent manner. In fact, seminiferous tubules showed degenerative changes within epithelium, namely vacuolation and sloughing of immature germ cells into the lumen in the group given the lowest dose (Fig.1 b,c). The high dosed group displayed more conspicuous injury within testis, namely strongly atrophic seminiferous tubules devoid of germs cells and strong vacuolation (Figs.1d-f).

The results of this study have shown an increased risk of adverse events in mice recei-ving $50 \mathrm{mg} / \mathrm{kg} / \mathrm{body}$ weight of $\left[\mathrm{Cr}(\mathrm{pic})_{3}\right]$. However, little potential for adverse reprodu-ctive and developmental effects namely on progeny was recently described for male mice fed a diet containing $200 \mathrm{mg} / \mathrm{kg} / \mathrm{day}\left[\mathrm{Cr}(\mathrm{pic})_{3}\right]^{[4-6]}$. In conclusion, concerns about using dietary supplements based on $\left[\mathrm{Cr}(\mathrm{pic})_{3}\right]$ remain to be elucidated in future work.

1. Stearns D. et al., Mutat. Res., 513:135-142, 2002.

2. Kim B. et al., Biol. Trace Elem. Res., 133:171-180, 2010.

3. Yazaki Y. et al., J. Altern. \& Complem. Med., 16:291-299, 2010.

4. McAdory D. et al., Biol. Trace Elem. Res., 143:1666-1672, 2011.

5. Vincent J., Dalton Trans., 39:3787-3794, 2010.

6. Anderson M.A. et al., Food Chem. Toxicol., 45:1097-1106, 2007.

This work was financed by CICECO, Aveiro University, Portugal. 

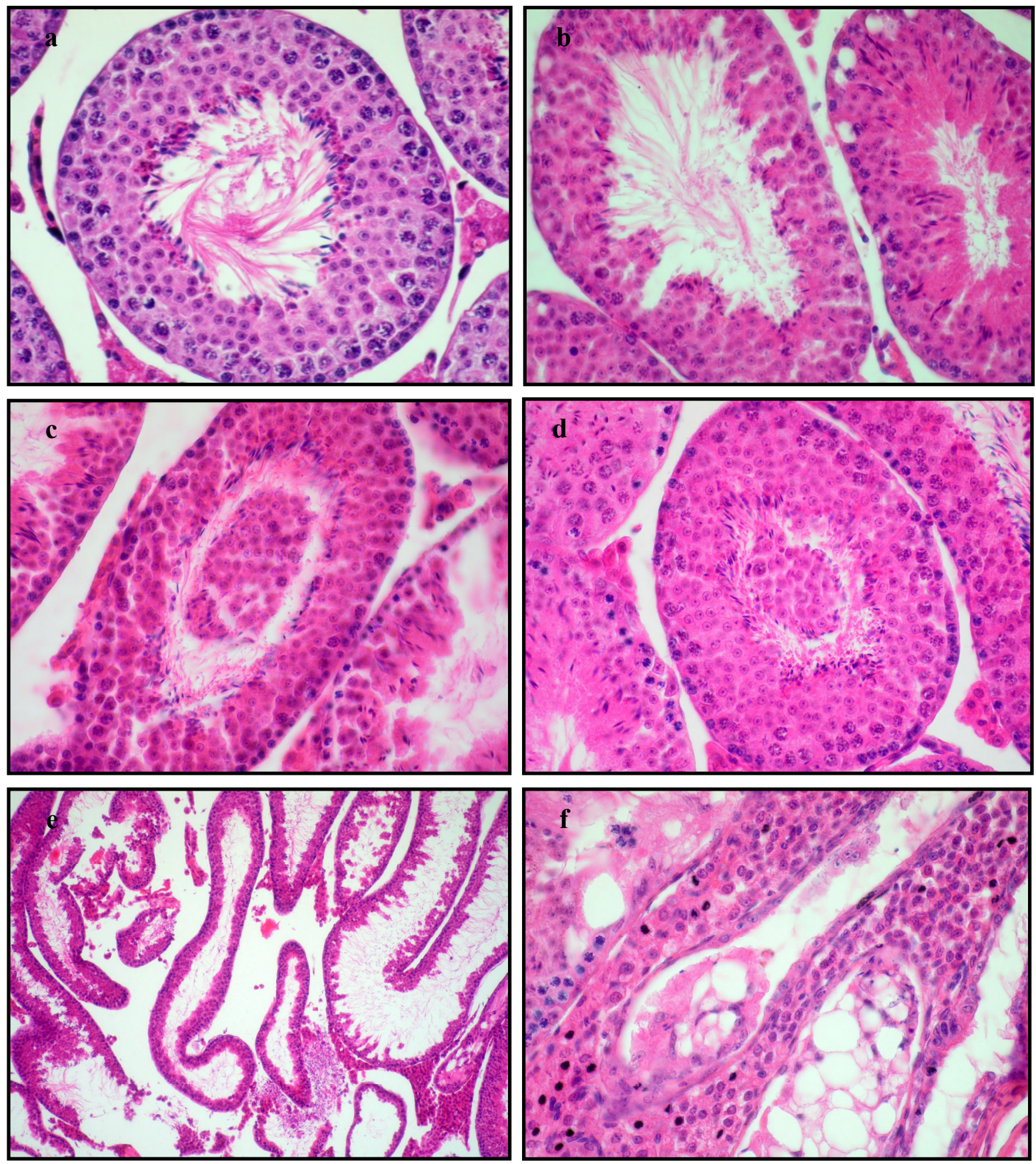

Fig 1. Representative sections of testis from control group (a); $25 \mathrm{mg} / \mathrm{kg} /$ body weight exposed group (b, c); $50 \mathrm{mg} / \mathrm{kg}$ body weight $\left[\mathrm{Cr}(\text { pic })_{3}\right]$-administered mice (d-f). Substantial deleterious effects were noted within seminiferous epithelium; Haematoxylin- Eosin stain; original magnification 400x. 